\title{
Viability of autologous fascia lata in heart valve replacements
}

\author{
J.C.R. LINCOLN ${ }^{1}, P$. A. RILEY,A.REVIGNAS, M G GENS, \\ D. N. ROSS, and J.K. ROSS \\ National Heart Hospital and University College Hospital Medical School, London
}

\begin{abstract}
A histological and radioautographic examination of 11 autologous fascia lata heart valves used in man is described. There was a significant decrease, exponential with time, in the number of fibroblasts per unit volume $(P<0.001)$. The collagen bundles were grossly disorganized and separated, suggesting a breakdown of the cross-linkage in the tissue. Redundant connective tissue on the surface of the valve cusp became oedematous and contained many trapped cells. A pseudoendothelium was formed within 10 days. Incorporation of tritium-labelled thymidine in the nuclei of the fibroblasts showed a sixfold reduction over 9 to 12 weeks following implantation, suggesting a failure of metabolism in these cells. The suitability of fascia lata for human heart valve replacement is discussed.
\end{abstract}

The construction of heart valve substitutes from autologous fascia lata using differing techniques has now become a well-established routine in many centres (Senning, 1967 ; Ionescu and Ross, 1969 ; Ionescu, Ross, Deac, Grimshaw, Taylor, Whitaker and Wooler, 1970). Probably the technique most commonly used is one where the fascia lata is sewn on to a supporting threepronged stent for ease of fabrication and insertion (Ionescu and Ross, 1969).

In a recent review of 76 patients who had undergone mitral valve replacement with a framemounted fascia lata valve, concern was expressed at the finding of contraction of the cusps of three of these fascia lata valves, with ensuing incompetence (Lincoln, Balcon, Emanuel, McDonald, Muir, Ross, Somerville, and Taylor, 1970). Because of these findings, a study was carried out on frame-mounted fascia lata valves which, for a variety of reasons, had been removed from patients in whom they had been inserted.

\section{MATERIAL}

1. Fascia lata taken from two patients, $\mathbf{A}$ and $\mathbf{B}$, who were undergoing cardiac surgery was made into routine histological sections and stained with haematoxylin and eosin, and these were used as controls. From 11 patients, $\mathbf{C}$ to $\mathbf{M}$, sections of valves which had been inserted for periods of time ranging from two days to 32 weeks were also made into histological sections and stained with haematoxylin and eosin.
2. Fascia lata from patient $B$ was divided into two parts. One part was immediately fixed in $10 \%$ formalin in $0.1 \mathrm{M}$ phosphate buffer, and the other part was left unfixed. Parts of both were prepared for radioautography. Fascia lata from patient I, who had had a valve in situ for nine weeks, and from patient $J$, who had had a valve in situ for 12 weeks, was prepared for radioautography. The time lapse which occurred between removing the fascia lata from the patients and its special preparation for these studies never exceeded 30 minutes.

\section{METHODS}

Radioautography can give information regarding the growth rate of cells by their ability to incorporate tritium( $\left.\mathbf{H}^{3}\right)$-labelled precursors of DNA.

A modification of the radioautographic technique of Kopriwa and Leblond (1962) was used. This technique is as follows:

1. Samples of fascia lata were incubated at $37^{\circ} \mathrm{C}$ for 48 hours in Eagles Minimum Essential Medium to which had been added $5 \mathrm{Ci}$ of methyl-tritiated thymidine.

2. After the period of incubation the tissue was washed for two hours with the culture medium to remove superabundant $\mathbf{H}^{3}$-labelled medium. Routine histological sections were made from each specimen after fixation in $10 \%$ formalin.

3. The sections were then covered with a thin film of Ilford K2 nuclear emulsion which was allowed to dry and were then stored for seven days at $5^{\circ} \mathrm{C}$ in a light-proof box.

1Correspondence to: J. C. R. L., Brompton Hospital, London, S.W.3 
4. After this time the emulsion-covered slides were developed with Ilford I.D. 19 developer, fixed in Ilford IF 2 solution, and then stained with haematoxylin and eosin.

Inclusion of the tritiated precursors of DNA in these histological sections can be assessed by routine light microscopy, because the beta ray emitted by the isotope has a short range and strikes the emulsion immediately next to the source, providing a positive picture which is seen microscopically as a black grain in or around the tissue.

Twenty consecutive fields, $0.22 \mathrm{~mm}^{2}$, were examined microscopically for:

1. collagen structure and volume

2. number of fibroblasts per $\mathrm{mm}^{3}$

3. number of fibroblasts labelled with tritiated thymidine

4. evidence of a pseudoendothelium

5. any other histological appearances.

RESULTS

A. FASCIA LATA CONTROL SPECIMEN The collagen was densely packed. There were numerous fibroblasts, some very long and interspersed between the collagen bundles. The average cell count was $2064.0 / \mathrm{mm}^{3}$. There was a striking difference between the superficial surface, which was thickly covered with loose connective tissue, in contrast to the deep surface which was relatively free of areolar tissue.

B. FASCIA LATA CONTROL SPECIMEN The collagen was densely packed, with minimal spacing between the collagen bundles. There were numerous fibroblasts. The average cell count was $2160.0 / \mathrm{mm}^{3}$. There was more connective tissue on the superficial side of the fascia lata. The percentage of fibroblasts which incorporated grains of $\mathbf{H}^{3}$-labelled thymidine was $38 \cdot 5 \%$ (Fig. 1).

B. FASCIA LATA CONTROL FIXED WITH FORMALIN BEFORE RADIOAUTOGRAPHY The collagen fibres were densely packed. No spaces were present between the bundles of collagen. The average number of fibroblasts was $2544.0 / \mathrm{mm}^{3}$. The percentage of fibroblasts which incorporated thymidine was $0.3 \%$ (Fig. 2).

C. FASCIA LATA FROM AORTIC VALVE AFTER 2 DAYS OF IMPLANTATION The collagen fibres were not so densely packed, with numerous spaces in the main body of the fascia. The average number of fibroblasts was $1027 \cdot 2 / \mathrm{mm}^{3}$. The loose connective tissue was filled with lymphocytes and round cells ; this zone was much thickened in comparison with the controls. The deep surface was relatively free of connective tissue. There was no evidence of a pseudoendothelium (Fig. 3).

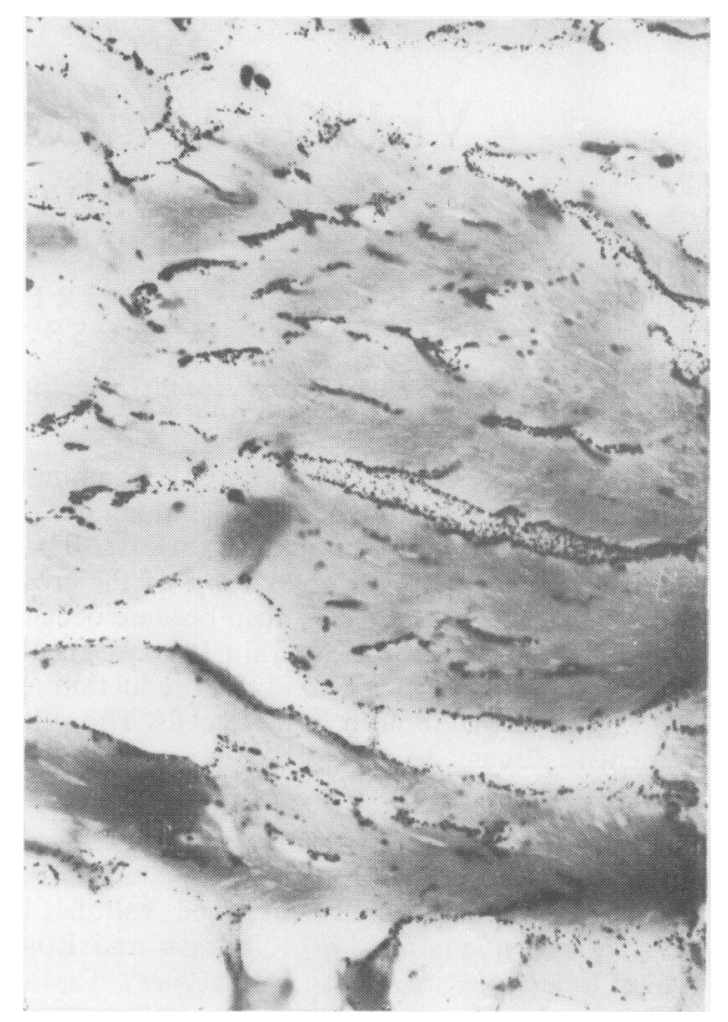

FIG. 1. Normal fascia lata with $\mathrm{H}^{3}$ thymidine incorporation. The collagen bundles are closely bound together. There is much incorporation of $\mathrm{H}^{3}$ thymidine (seen as black grains) in and around the many fibroblasts. H. and E. $\times$ 253. Control.

D. FASCIA LATA FROM MITRAL VALVE AFTER 4 DAYS OF IMPLANTATION This was a poor histological preparation. There was evidence of spaces between the bundles of collagen. The average number of fibroblasts was $912.0 / \mathrm{mm}^{3}$.

E. FASCIA LATA FROM AORTIC VALVE AFTER 10 DAYS OF IMPLANTATION The collagen fibres were loosely packed. Few fibroblasts were seen; the average number was $441 \cdot 6 / \mathrm{mm}^{3}$. There was a wide zone of loose connective tissue packed with lymphocytes, red' blood cells, and round cells. The outer layer of this zone appeared to be forming a pseudoendothelium which was also forming on the deep surface.

F. FASCIA LATA FROM MITRAL VALVE AFTER 21 DAYS OF IMPLANTATION The collagen bundles were loosely packed. Few fibroblasts were seen; the 


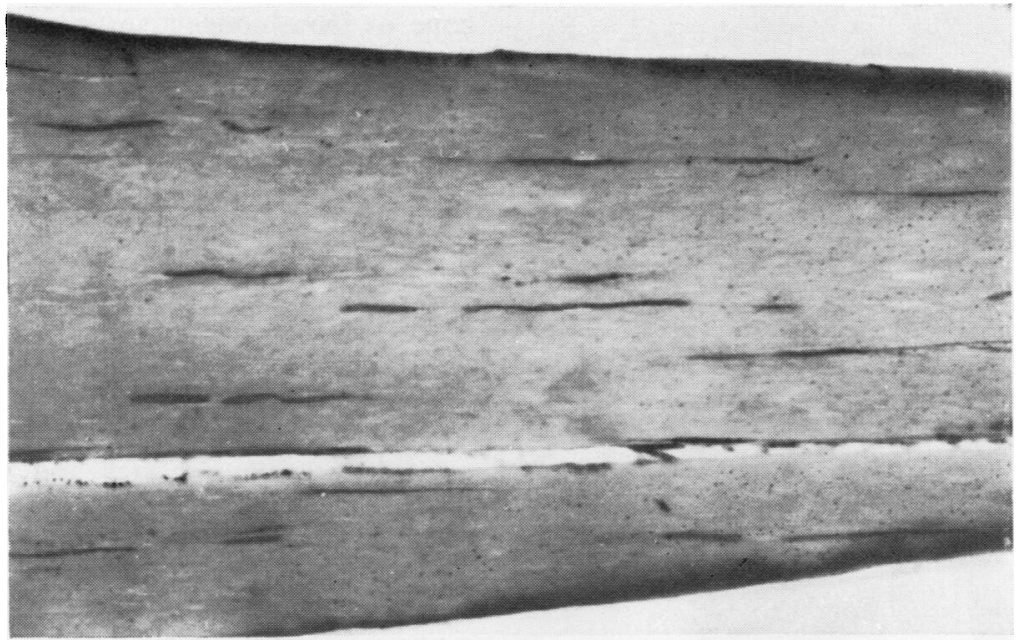

FIG. 2. Normal fascia lata with $H^{3}$ thymidine incorporation after fixation with formalin solution. There is no incorporation of the $H^{3}$ thymidine in or around the fibroblasts. H. and E. $\times 240$. Control.

average number was $9 \cdot 6 / \mathrm{mm}^{3}$. There was a wide band of loose connective tissue filled with round cells and lymphocytes on the superficial side of the fascia. The uoper edge of the cusp was seen to be rounded and turned over, being stuck down on to the connective tissue (Fig. 4).

G. FASCIA LATA FROM AORTIC VALVE AFTER 21 DAYS OF IMPLANTATION Many spaces were seen between the bundles of collagen. There were few fibroblasts interspersed in collagen bundles. The average number of cells was $384.0 / \mathrm{mm}^{3}$. There was thickened connective tissue on the superficial side of the fascia lata. There was a well-marked pseudoendothelium on the superficial and deep side of the tissue. The upper edge of this section of the cusp showed a thread of loose tissue.

H. FAScia LATA FROM Mitral VALVE AFTER 7 WEEKS OF IMPLANTATION The collagen bundles were loosely packed. There were few fibroblasts; the average number was $374.4 / \mathrm{mm}^{3}$. There was a well-marked zone of connective tissue filled with lymphocytes and round cells on the superficial

FIG. 3. Fascia lata removed from a heart valve after two days' implantation. There is a wide zone of loose connective tissue on the cusp margin which has much cellular infiltration. $H$. and $E$. $\times 253$.

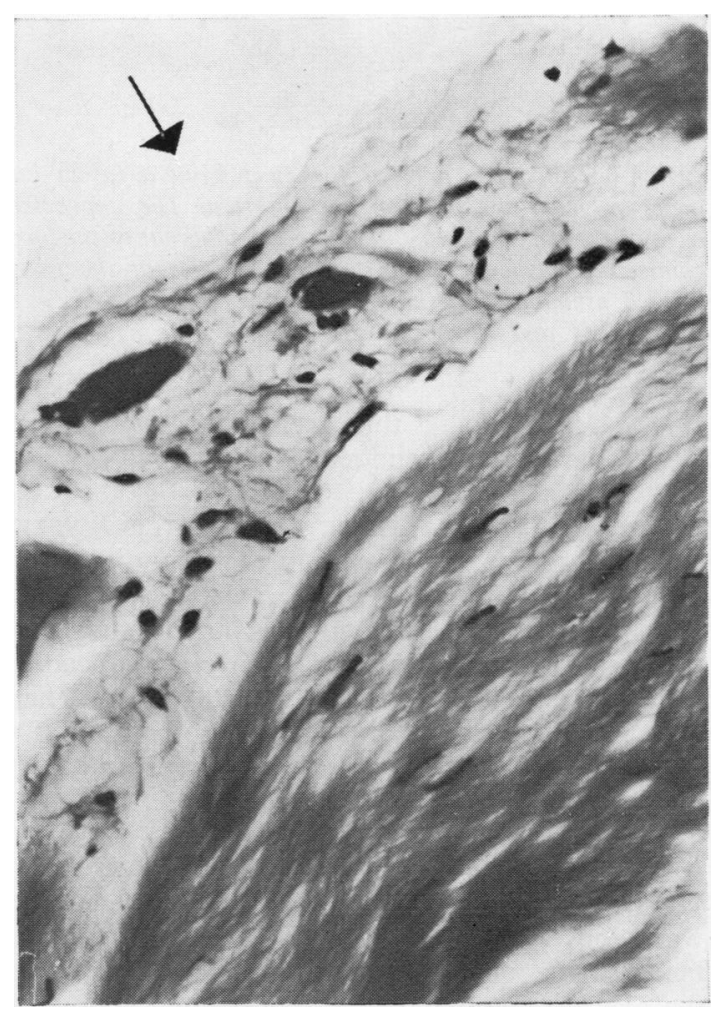




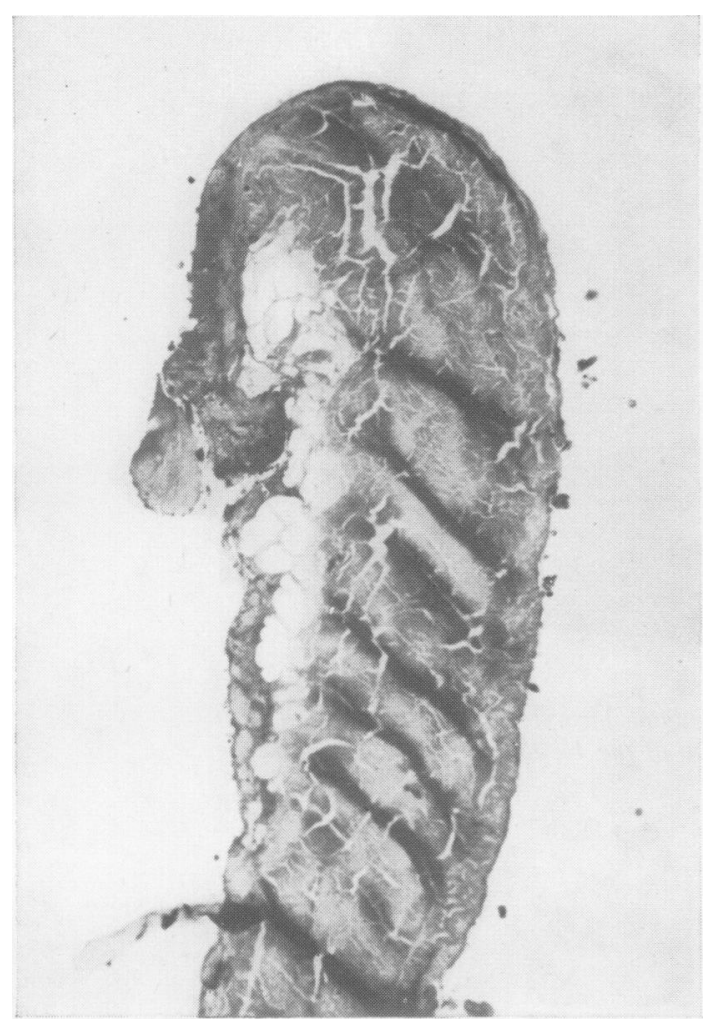

FIG. 4. The upper part of the cusp from a fascia lata heart valve after 21 days' implantation. The upper free edge of the cusp is turned down and is adherent to the loose connective tissue on the superficial surface of the fascia lata. A pseudoendothelium has formed on both surfaces of the cusp. H. and E. $\times 35$. Case F.

side of the fascia; this area was covered with a well-developed pseudoendothelium.

I. FASCIA LATA FROM AORTIC VALVE AFTER 9 WEEKS OF IMPLANTATION The collagen bundles were grossly disorganized with many spaces and lacunae in which lymphocytes and round cells were trapped. The fibroblasts were reduced in number. The average count was $288 / \mathrm{mm}^{3}$. There was no evidence of a pseudoendothelium. The percentage of fibroblasts which incorporated $\mathrm{H}^{3}$ labelled thymidine was 6\% (Fig. 5).

J. FASCIA LATA FROM MITRAL VALVE AFTER 12 WEEKS OF IMPLANTATION The collagen bundles were loosely bound together, with many spaces between the bundles. There were few fibroblasts, the average number being $460 \cdot 8 / \mathrm{mm}^{3}$. There was a well-marked pseudoendothelium covering a wide zone of loose connective tissue on the superficial layer of the fascia. The upper edge of the cusp was somewhat rounded off. The percentage of fibroblasts which incorporated tritiated thymidine was $5 \%$.

K. FASCIA LATA FROM Mitral VALVE AFTER 32 WEEKS OF IMPLANTATION The collagen bundles were loosely bound together. There were many spaces between the bundles. There were few fibroblasts, the average number being $144 \cdot 0 / \mathrm{mm}^{3}$. There was a well-marked pseudoendothelium over a deep zone of connective tissue, which was packed with lymphocytes and round cells. The deep surface was free of connective tissue but also had a pseudoendothelium.

L. FASCIA LATA FROM MITRAL VALVE AFTER 32 WEEKS OF IMPLANTATION The collagen bundles

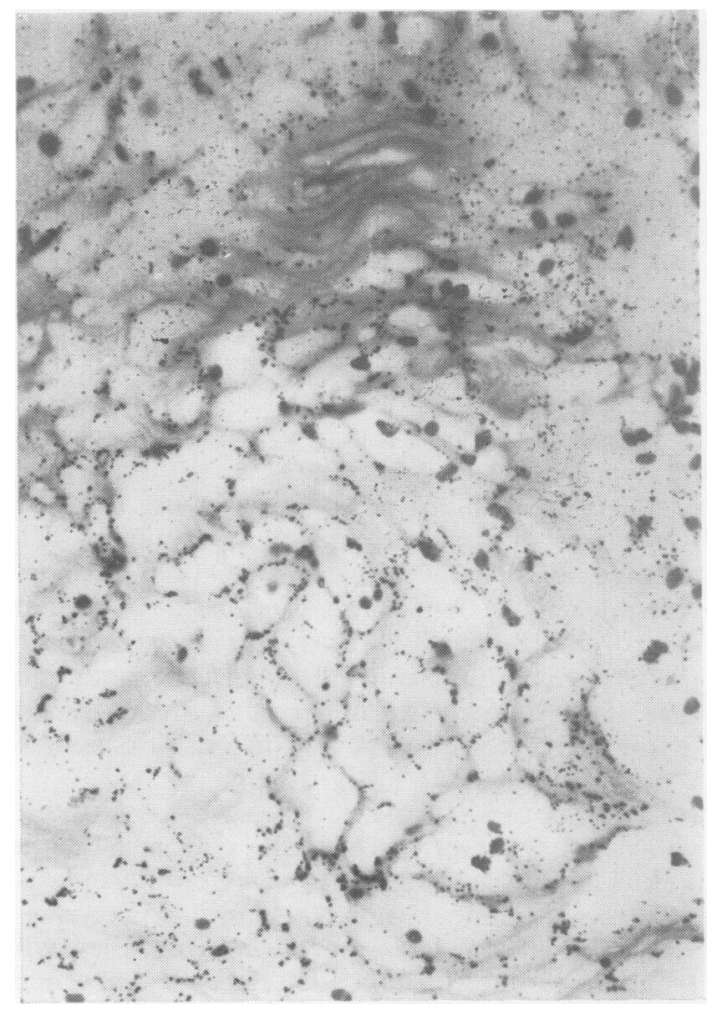

FIG. 5. Disorganization of the collagen bundles in a fascia lata heart valve after nine weeks' implantation. There are very few fibroblasts with no incorporation of $\mathrm{H}^{3}$ thymidine. There is cellular infiltration into the substance of the tissue by round cells and red blood cells. $H$. and $E . \times 250$. Case I. 
were loosely bound with few fibroblasts; the average number was $288 / \mathrm{mm}^{3}$. There was a very wide zone of cellular infiltration in connective tissue on the superficial side of the fascia. There was good pseudoendothelialization. The upper edge of the cusp was turned down.

M. FASCIA LATA FROM MITRAL VALVE AFTER 32 WEEKS OF IMPLANTATION The collagen bundles were very disorganized. There were few fibroblasts $-336.0 / \mathrm{mm}^{3}$. The upper edge of the cusp was rounded off. A good pseudoendothelium was seen.

\section{DISCUSSION}

Because autologous fascia lata has great strength and flexibility and is easily obtainable, its use in
T A B L E

NUMBER OF FIBROBLASTS AND THYMIDINE INCORPORATION IN 11 FASCIA LATA HEART VALVES

\begin{tabular}{|c|c|c|}
\hline $\begin{array}{c}\text { Fascia Lata Heart Valves } \\
\text { (length of implantation } \\
\text { in heart) }\end{array}$ & $\underset{\mathrm{mm}^{2}}{\text { Fibroblasts/ }}$ & $\begin{array}{l}\% \text { of Fibroblasts } \\
\text { with Incorporated } \\
\mathbf{H}^{3} \text { Thymidine }\end{array}$ \\
\hline 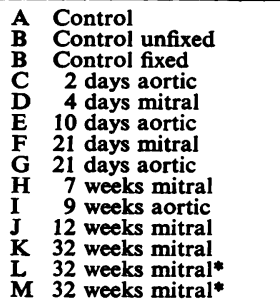 & $\begin{aligned} 2064 \cdot 0 \\
2160 \cdot 0 \\
2544 \cdot 0 \\
1027 \cdot 2 \\
912 \cdot 0 \\
441 \cdot 6 \\
9 \cdot 6 \\
384 \cdot 0 \\
374 \cdot 4 \\
288 \cdot 0 \\
460 \cdot 8 \\
144 \cdot 0 \\
288 \cdot 0 \\
336 \cdot 0\end{aligned}$ & $\begin{array}{r}38.5 \\
0.3\end{array}$ \\
\hline
\end{tabular}

There is a six-fold decrease in $\mathrm{H}^{3}$ thymidine incorporation in fascia lata which had been implanted for 12 weeks. There is a fall in the number of fibroblasts in both the mitral and aortic positions.

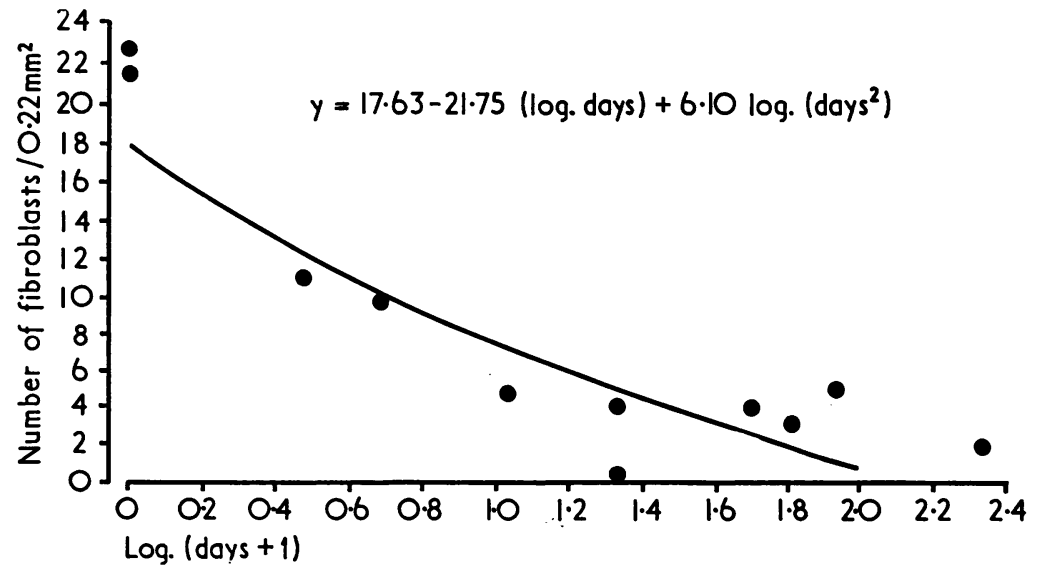

FIG. 6. A regression curve of the number of fibroblasts per $0.22 \mathrm{~mm}^{2}$ in fascia lata which had been used in 11 patients. Length of implantation 2 days to 32 weeks. There is a significant decrease in the numbers of fibroblasts per unit volume of tissue $(\mathrm{P}<0.001)$. The decrease is exponential with respect to time after implantation.

REGRESSION OF FIBROBLASTS ON TIME TO ESTIMATION (ESTIMATIONS ON 11 PATIENTS)

\begin{tabular}{|c|c|c|c|c|c|}
\hline Source of Variation & Sum of Squares & $\begin{array}{c}\text { Degrees } \\
\text { of Freedom }\end{array}$ & Mean Square & F-ratio & Probability \\
\hline $\begin{array}{l}\text { Total (fibroblasts) } \\
\text { Regression on log. (days) and log. (days) } \\
\text { Regression on log. (days) } \\
\text { Regression on log. (days) }{ }^{2} \text { given log. (days) } \\
\text { Residual (A) }\end{array}$ & $\begin{array}{r}585.9818 \\
553 \cdot 2956 \\
445 \cdot 4869 \\
107.8087 \\
32.6862\end{array}$ & $\begin{array}{r}10 \\
2 \\
1 \\
1 \\
8\end{array}$ & $\begin{array}{r}276.6478 \\
445.4869 \\
107.8087 \\
4.0858\end{array}$ & $\begin{array}{l}67 \cdot 71 \\
26 \cdot 38\end{array}$ & $\begin{array}{l}<0.001 \\
<0.001\end{array}$ \\
\hline
\end{tabular}

Linear regression of fibroblasts on log. (days) gives $F_{1,0}=28.54(P<0.001)$.

$y=17.63-21 \cdot 75$ (log. days) $+6 \cdot 10 \log .\left(\right.$ days $\left.^{2}\right)$

\begin{tabular}{|c|c|c|} 
Log. & Days & \multicolumn{1}{|c|}{$y$} \\
\hline 0 & 0 & 17.63 \\
1 & 9 & 7.55 \\
2 & 99 & 0.48
\end{tabular}


constructing heart valve substitutes would appear to confer the obvious advantages of a biological valve not involved in rejection, not requiring anticoagulation, and with the possibility of the tissue remaining viable and maintaining its normal characteristics.

In the leg, fascia lata is perforated by numerous small neurovascular bundles en route to the subcutaneous tissues. The main source of blood supply to the fascia lata arises from the adjacent subcutaneous tissue. There is no obvious supply to the deep surface. Macroscopic examination of the deep surface of the fascia lata demonstrates a shiny, glistening surface covered with a small amount of loose connective tissue which is easily removed. In contrast, the superficial surface has densely attached areolar and connective tissue which is vascular and is difficult to remove. In the construction of valves from the fascia it is advantageous from the point of view of their subsequent physiological function to minimize the amount of this loose connective tissue in the graft. This factor, together with the relatively atraumatic manner in which the valve is inserted, raises the question whether the fascia lata is capable of being adequately vascularized in the grafted sites. The gross appearance and the histology of longstanding grafts (cases $I$ and J) would seem to suggest that, at least in some cases, the fascia is insufficiently vascularized and the graft is breaking down. Many grafts showed infiltration with lymphocytes and macrophages and the gross structure of the valves was progressively less satisfactory with longer grafting times. The pseudoendothelium, which was well formed after 10 days in situ, was not affected by the changes within the graft. The upper edge of the fascia lata cusp was frequently rounded off and in one patient had turned down and become adherent to the loose connective tissue. In patient $G$ there was a pseudofilamentous thread streaming from the upper edge of the cusp.

To determine whether the breakdown of these grafts was due to special circumstances or whether the phenomenon is a general one affecting all fascia lata valve grafts, cell counts were made in the available material. These show that in fascia lata heart valves there is a significant decrease in the number of fibroblasts per unit volume of tissue $(P<0.001)$ (Table). This decrease was exponential with respect to time after implantation, as shown in Figure 6. In the control specimens there were many fibroblasts, often long and spindle shaped ; in contrast to this, the fibroblasts in the fascia lata after use in the heart valve substitute were shortened and less fusiform. The decrease in the number and the change in morphology of the fibroblasts could be related to an increase in hydration of the collagen. After fascia lata has been implanted in the heart as a frame-mounted heart valve substitute, the bundles of collagen separate with many intervening spaces. This appearance was seen in fascia lata as early as two days after implantation. It is possible that an increase in hydration of the mucopolysaccharide ground substance may cause separation of the collagen bundles, or there may be a failure of cross-linkage. Allowing for this, it is nevertheless unlikely that the reduction in cell numbers per unit volume is entirely due to dilution. This is confirmed by the results of the thymidine incorporation studies in cases B, I, and $\mathrm{J}$, which gave fibroblast labelling indices of $38.5 \%, 6 \%$, and $5 \%$ respectively-a six-fold reduction over 9 to 12 weeks following implantation (Table). These results are consistent with an absolute diminution in the numbers of viable connective tissue cells in the fascia lata grafts.

These changes confirm the experimental work of Brea, Allen, and Muller (1965), Flege, Rossi, Auer, and Ehrenhaft (1967), Gilbert, Mansour, Sanders and Gravanis (1968), and Myers and Miller (1969), who demonstrated that fascia lata valves in the dog underwent thickening and' cicatricial contraction and became incompetent in the long term. The disorganization of the collagen bundles, coupled with a significant decrease in the number of fibroblasts in fascia lata which has been implanted as a heart valve substitute, together with the clinical findings of contraction of the fascia lata in several patients, suggest that human fascia lata is not maintaining its in vivo characteristics.

\section{REFERENCES}

Brea, C. A. Jr., Allen, M. S. Jr., and Muller, W. H. Jr. (1965). Superior vena cava replacement with autogenous fascia. An experimental study. Amer. Surgn., 31, 610.

Flege, J. B. Jr., Rossi, P. N., Auer, J. E., and Ehrenhaft, J. L. (1967). Technique of mitral valve replacement with autologous fascia lata. J. thorac. cardiovasc. Surg., 54, 222.

Gilbert, J. W. Jr., Mansour, K., Sanders, S., and Gravanis, M. B. (1968). Experimental reconstruction of the tricuspid valve with autologous fascia lata. Arch. Surg., 97, 149.

Ionescu, M. I., and Ross, D. N. (1969). Heart-valve replacement with autologous fascia lata. Lancet, 2, 335.

- Deac, R., Grimshaw, V. A., Taylor, S. H., fascia lata for heart valve replacement. Thorax, 25, 46.

Kopriwa, B. M., and Leblond, C. P. (1962). Improvements in the coating technique of radioautography. J. Histochem. Cytochem., 10, 269. 
Lincoln, C., Balcon, R., Emanuel, R., McDonald, L., Muir, J., Ross, D., Somerville, J., and Taylor, J. (1970). Mitral valve replacement with fascia lata. Cardiovasc. Res., 4, suppl.: VI World Congress of Cardiology, London, 1970. Abstracts of Papers, p. 200.
Myers, W. O., and Miller, D. R. (1969). Autogenous fascial aortic valves in dogs. J. thorac. cardiovasc. Surg., 57, 805.

Senning A. (1967). Fascia lata replacement of aortic valves. J. thorac. cardiovasc. Surg., 54, 465. 